\title{
Smad3 mediates immediate early induction of Id1 by TGF- $\beta$
}

\author{
Yao-Yun Liang ${ }^{1}$, F Charles Brunicardi ${ }^{1},{\mathrm{Xia} \text { Lin }^{1}}^{1}$ \\ ${ }^{1}$ Michael E. DeBakey Department of Surgery, Baylor College of Medicine, BCM-390, Research Tower, Room R711, One Baylor \\ Plaza, Houston, TX 77030, USA
}

Id1 is a member of the inhibitor of differentiation (Id) protein family that regulates a wide range of cell functions. Previous studies have shown that expression of the IdI gene is down-regulated by TGF- $\beta$ in epithelial cells, whereas it is up-regulated by BMP in a variety of cell types. During our study of the biological function of TGF- $\beta 1$, we found that Id1 can be strongly up-regulated by TGF- $\beta 1$ in the human mammary gland epithelial cell line MCF10A. Quantitative real-time RT-PCR has revealed as high as 7.5-fold induction of IdI mRNA by TGF- $\beta 1$ in MCF10A cells after 1 $h$ of TGF- $\beta 1$ stimulation, and this induction does not require de novo protein synthesis. Using Smad knockdown and knockout approaches, we have identified Smad3 as the responsible R-Smad for mediating transcriptional activation of the IdI gene. Chromatin immunoprecipitation assay confirms that Smad3 and Smad4 bind to the upstream region of the Id1 gene. Our results demonstrate that Smad3, but not Smad2, mediates TGF- 11 -dependent early transcriptional induction of Id1.

Keywords: TGF- $\beta$ signaling, Id1 transcription, Smad, chromatin

Cell Research (2009) 19:140-148. doi:10.1038/cr.2008.321; published online 16 December 2008

\section{Introduction}

The TGF- $\beta$ superfamily signaling is mediated by cell surface type I and type II receptors (i.e. T $\beta R I$ and T $\beta$ RII in the case of TGF- $\beta$ ligands), both of which are serine/ threonine kinases, and intracellular Smad proteins $[1$, 2]. Upon ligand binding to the cell surface T $\beta R I I, T \beta R I I$ phosphorylates the downstream kinase T $\beta$ RI. The activated T $\beta R I$ then phosphorylates the two TGF- $\beta$-specific R-Smad proteins, i.e. Smad2 and Smad3, at their Cterminal SXS motifs. Phospho-Smad2/3 form a complex with the common mediator Smad4, and the heteromeric Smad complex then accumulates in the nucleus, where it binds to a Smad-binding element (SBE) AGAC and cooperates with a large number of transcription co-regulators at the promoters of diverse arrays of target genes [3]. On many TGF- $\beta$ target gene promoters, Smads cooperate with a context-dependent sequence-specific DNA-binding transcription activator to activate the gene promoter.

Correspondence: Xia Lin

Tel: +1-713-798-4899

Fax: +1-713-798-4093

E-mail: xialin@bcm.edu

Received 16 July 2007; revised 5 August 2008; accepted 8 August 2008; published online 16 December 2008
For instance, Smads physically interact and functionally synergize with $\mathrm{Sp} 1$ to up-regulate the $\mathrm{p} 15$ transcription in response to TGF- $\beta$ [4]. Smads also mediate active repression of certain genes such as the $I d 1$ gene in cooperation with ATF3 [5].

Id1 is a member of the helix-loop-helix (HLH) protein family that comprises four members (Id1 through 4) [6]. They mostly act as negative transcriptional regulators in many biological processes such as cell differentiation, cell senescence, neurogenesis, apoptosis and angiogenesis [6-13]. As all of them lack a DNA-binding domain, they heterodimerize with and inhibit the function of basic HLH (bHLH) transcription factors [6, 14], for examples, myogenic regulatory factors, such as MyoD, myogenin, Myf5 and MRF4/Myf6 [15, 16], or class A of E proteins, such as E12, E47, E2-2 and ITF-2 [15, 17-19]. Inhibitor of differentiation (Id) proteins also interact with nonHLH proteins such as Ets2 [20] and MIDA1 [21] to regulate their activities. It is reported that Id 1 protein is required for BCR/ABL-mediated leukemogenesis [22]. A series of downstream target genes of Id 1 have been identified by hybridization and microarray analysis $[10$, $23,24]$. Id 1 can localize to centrosomes and induce abnormal centrosome numbers in human primary cells and tumor cell lines [25]. Expression of Id1 is regulated by a variety of ligands, including BMPs of the TGF- $\beta$ super- 
family [26].

During the course of our study on TGF- $\beta$-dependent gene regulation, we noticed that $I d l$ gene could be transiently, yet significantly, induced by TGF- $\beta$. Although both positive and negative transcriptional regulation of Id 1 by TGF- $\beta 1$ has been reported $[5,27]$, it is generally believed that $I d 1$ gene is repressed for TGF- $\beta$ to achieve its cytostatic and stress responses in epithelial cells. Furthermore, Id1 induction in certain cell types may be mediated through the ALK1-activated Smad1 pathway, but not through the T $\beta R I$-activated $S \operatorname{Smad} / 3$ pathway [28]. Therefore, the molecular mechanism underlying transcriptional activation of Id 1 by TGF- $\beta 1$ still remains elusive. In this study, we have demonstrated that TGF- $\beta 1$ transiently and profoundly induces transcription of Id 1 in human epithelial cells and mouse embryonic fibroblasts (MEFs). The Id1 induction is then switched to repression after continuous TGF- $\beta$ stimulation. For the first time, we have determined that Smad3, but not Smad2, mediates TGF- $\beta 1$-dependent transcriptional induction of the Idl gene in human epithelial cells and MEFs. The Id1 induction is directly associated with the binding of Smad3 to the upstream region of the $I d 1$ promoter and TGF- $\beta$ induced acetylation of histones $\mathrm{H} 3$ and $\mathrm{H} 4$.

\section{Results}

\section{Id1 is induced by TGF- $\beta 1$ in various human epithelial cell lines}

Although previous studies have reported both repression and induction of the $I d 1$ gene by TGF- $\beta[5,27]$, it is a dominant view that TGF- $\beta$ primarily represses Id 1 transcription [5]. Most of these studies focus on the regulation of the $I d 1$ gene with prolonged TGF- $\beta 1$ treatment (e.g. $>3 \mathrm{~h}$ TGF- $\beta 1$ treatment). It remains unclear whether the induction or repression is cell type-specific or can take place in the same cell. In this study, we re-examined the regulation of Id 1 expression by TGF- $\beta 1$, particularly by short TGF- $\beta 1$ exposure. The steady-state level of endogenous Id 1 protein was analyzed in three human cell lines: MCF10A, HaCaT and HeLa cells. These cells were treated with TGF- $\beta 1$ for various time periods from 15 min up to $4 \mathrm{~h}$, and the level of Id1 protein was measured by anti-Id1 western blotting analysis. In order to eliminate the effect of residual TGF- $\beta 1$ in serum-containing medium, cells were serum starved overnight, and the TGF- $\beta 1$ treatment was carried out in serum-free medium. As shown in Figure 1, Id1 protein could be induced transiently by TGF- $\beta 1$ in all the three human cell lines. Id 1 protein induction was observed at $15 \mathrm{~min}$ of TGF- $\beta 1$ treatment, and Id 1 protein level reached the peak at $1 \mathrm{~h}$ after TGF- $\beta 1$ addition, with an exception that Id1 protein was more gradually induced and reached its peak at $1.5 \mathrm{~h}$ in MCF10A cells. AS the positive controls, we observed a rapid induction in phosphorylation of Smad2 and Smad 3 with 15 min of TGF- $\beta 1$ treatment. After reaching its peak, Id1 protein level gradually decreased even with the presence of TGF- $\beta 1$. In accordance with previous reports $[5,27]$, the Id 1 protein level at $4 \mathrm{~h}$ after TGF- $\beta 1$ treatment was below the basal level, indicating that the Idl gene was repressed or Id1 protein was rapidly degraded. Thus, Id 1 protein is transiently induced by TGF- $\beta 1$ in various human cell lines.

\section{Id1 is an immediate early response gene of TGF- $\beta 1$}

To determine whether the early increase in the Id1 protein level is attributed to the increased Id1 transcription, real-time RT-PCR was carried out to quantify the Id 1 mRNA level in MCF10A cells. Total RNAs were prepared from MCF10A cells that were treated with TGF- $\beta 1$ for various time periods up to $12 \mathrm{~h}$. As shown in Figure $2 \mathrm{~A}$ and $2 \mathrm{~B}$, the peak of $I d 1$ mRNA induction was ob-
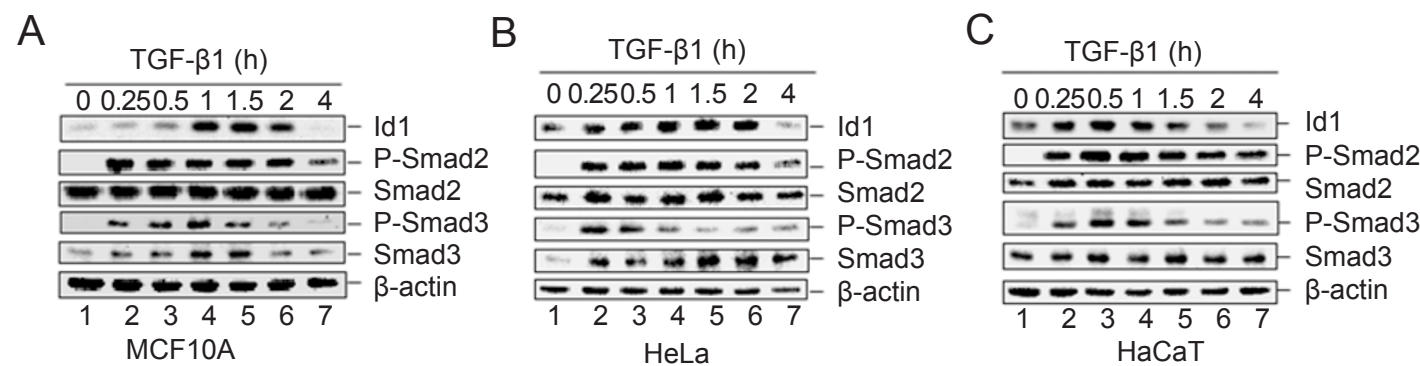

Figure 1 TGF- $\beta 1$ induces Id1 expression in human epithelial cells. (A) TGF- $\beta 1$ induces Id1 expression in MCF10A cells. MCF10A cells at $80 \%$ confluence were starved in serum-free medium for $12 \mathrm{~h}$ and then treated with TGF- $\beta 1$ ( $5 \mathrm{ng} / \mathrm{ml})$ for the indicated time periods. Cell lysates were harvested with SDS sample buffer and loaded on a $12 \%$ SDS-PAGE gel for western blotting analysis using antibodies against the indicated protein. (B) TGF- $\beta 1$ induces Id 1 expression in HeLa cells. Experimental procedures are the same as described for MCF10A cells. (C) TGF- $\beta 1$ induces Id1 expression in HaCaT cells. Experimental procedures are the same as described for MCF10A cells. 
served at $1 \mathrm{~h}$ after TGF- $\beta 1$ stimulation regardless of the growth conditions. At the peak time, TGF- $\beta 1$ induced a 2.2- and 7.5-fold increase of Id1 mRNA when MCF10A cells were cultured in low-serum (Figure 2A) and serumfree media (Figure 2B), respectively. This result suggests that the increased level of Id1 protein in Figure 1 results from the increased level of IdI mRNA induced by TGF$\beta 1$. As observed with Id 1 protein level, Id 1 mRNA level decreased gradually after $1 \mathrm{~h}$ of TGF- $\beta 1$ treatment, and the level of $I d 1$ mRNA returned to the basal level after $4 \mathrm{~h}$ of TGF- $\beta 1$ treatment. Later time points showed that prolonged TGF- $\beta 1$ treatment caused the decline of IdI mRNA to fall below the basal level, indicating a repres-
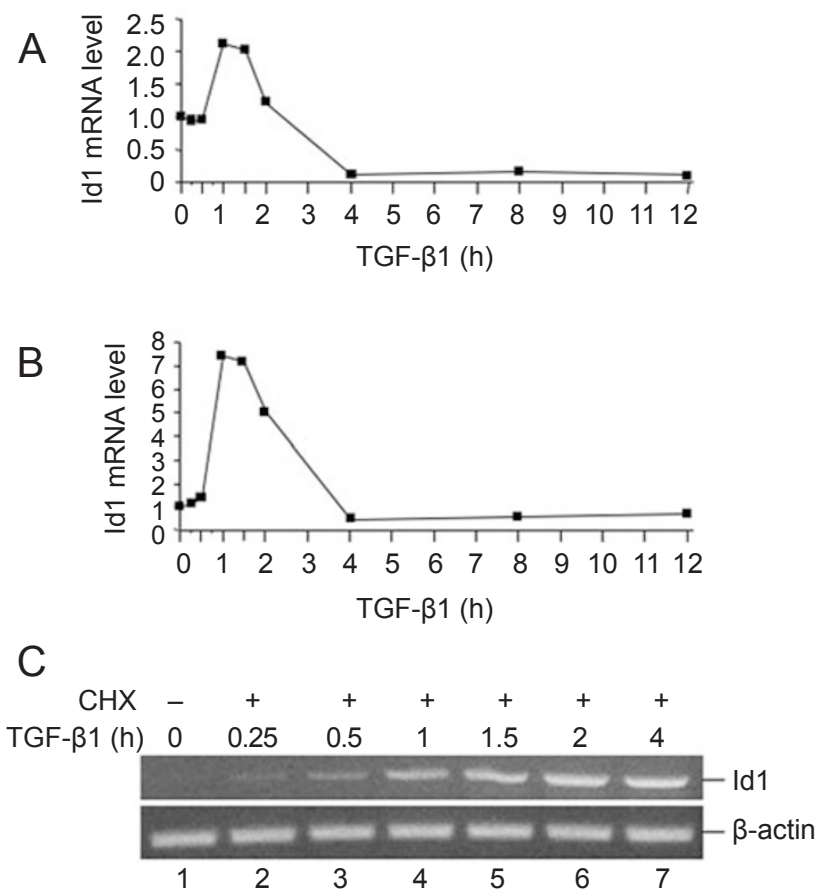

Figure 2 TGF- $\beta 1$ induces Id 1 mRNA independently of new protein synthesis. (A) TGF- $\beta 1$ moderately induces $I d 1 \mathrm{mRNA}$ in MCF10A cells. MCF10A cells were grown in the presence of $0.2 \%$ horse serum to $80 \%$ confluence and treated with TGF- $\beta 1$ $(5 \mathrm{ng} / \mathrm{ml})$. Cells were harvested at the indicated time, total RNA was extracted and subjected to subsequent quantitative RTPCR analysis of Id1 mRNA. (B) TGF- $\beta 1$ rapidly and profoundly induces Id1 mRNA in serum-starved MCF10A cells. MCF10A cells were grown to $80 \%$ confluence, starved in serum-free medium for $12 \mathrm{~h}$ and then treated with TGF- $\beta 1$ ( $5 \mathrm{ng} / \mathrm{ml})$. Cells were harvested at the indicated time, total RNA was extracted and subjected to subsequent quantitative RT-PCR analysis of Id 1 mRNA. (C) Id1 is an early response gene to TGF- $\beta 1$. MCF10A cells were first serum-starved for $12 \mathrm{~h}$ and then treated with TGF- $\beta 1(5 \mathrm{ng} / \mathrm{ml})$ in the presence of protein synthesis inhibitor CHX. PCR products were separated by a $1.5 \%$ agarose gel. DNA bands correspond to the full length of $I d 1 \mathrm{cDNA}$. sion of the Id 1 transcription. Therefore, TGF- $\beta 1$ has a dual effect on Id1 transcription. Whilst cells exposed to TGF- $\beta 1$ for short time $(<1 \mathrm{~h})$ exhibit an acute response to induce Id 1 mRNA, chronic TGF- $\beta 1$ treatment ( $>4 \mathrm{~h}$ ) has a repressive effect on Id 1 transcription.

The observation that IdI mRNA was induced by TGF$\beta 1$ within $1 \mathrm{~h}$ implies that Id 1 induction by TGF- $\beta 1$ is an immediate early response, independent of new protein synthesis. To confirm this, we treated MCF10A cells with the protein synthesis inhibitor cycloheximide (CHX) for $30 \mathrm{~min}$ prior to and during TGF- $\beta 1$ stimulation. RTPCR analysis showed that CHX treatment did not affect the early induction of Id 1 transcription by TGF- $\beta 1$ (Figure 2C). Interestingly, under such conditions TGF$\beta 1$-induced $I d 1$ mRNA continues to rise with continuous TGF- $\beta 1$ stimulation (up to $4 \mathrm{~h}$, Figure $2 \mathrm{C}$ ). These results suggest that TGF- $\beta 1$-mediated early induction of Id 1 does not require new protein synthesis, whereas TGF- $\beta 1$ mediated late repression of Id1 transcription is dependent on de novo protein synthesis. The observation that Id 1 repression requires new protein synthesis is consistent with a previous report that TGF- $\beta$-induced ATF3 mediates Id1 repression [5].

TGF- $\beta 1$-dependent Id1 induction does not require Smad2

$\mathrm{Smad} 2$ and Smad3 are key intracellular signal transducers for TGF- $\beta 1$ responses. Here we took a lossof-function approach to determine whether TGF- $\beta 1$ mediated Id 1 induction is a Smad-dependent response. As a first step, we established cell lines derived from MCF10A that stably express Smad2 shRNA (shSmad2). The level of Smad3 was unchanged when $80 \%$ knockdown of endogenous Smad2 was achieved (Figure 3A). Control and Smad 2 shRNA cells were then treated with TGF- $\beta 1$ for different time periods, and Id1 protein level was determined by western blotting analysis (Figure 3A). Compared to control cells, knockdown of Smad2 had no effect on the induction profile of Id 1 protein by TGF- $\beta 1$ (Figure 3A).

To rule out the possibility that a low level of Smad2 in Smad2 shRNA cells suffices to mediate TGF- $\beta 1$ induced Id1 expression, we analyzed the Id 1 induction in Smad2-null MEFs (Smad2KO). Smad2-null MEFs were treated with TGF- $\beta 1$ for $1 \mathrm{~h}$, and Id1 protein level was determined by western blotting analysis. We found that Smad2-null MEFs responded well to TGF- $\beta 1$ to induce Smad3 phosphorylation and Id1 expression (Figure 3C, lane 4). In addition, we included BMP2 as a control because it is a well-known inducer of Id1 expression [29, $30]$. As expected, BMP2 normally induces Smad1 phosphorylation and does not require Smad2 for Id1 induction (Figure 3C, lane 2). These data suggest that Smad2 
A

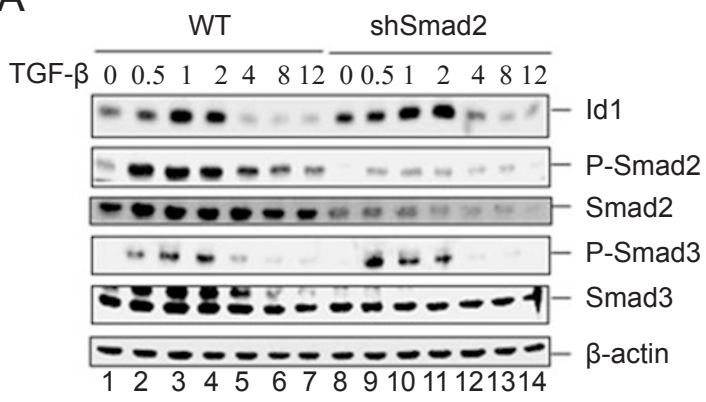

B

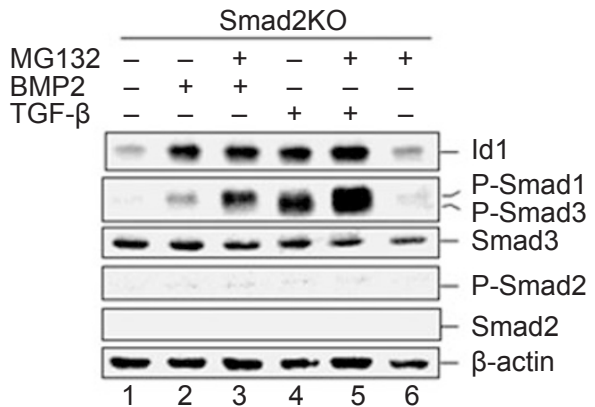

Figure 3 Smad2 is dispensable for Id1 induction by TGF- $\beta 1$. (A) Knockdown of Smad2 expression has no effect on TGF$\beta$-induced Id1 expression in MCF10A cells. MCF10A cells control (WT) and stable cells expressing shRNA against Smad2 (shSmad2) were grown in serum-free medium for $12 \mathrm{~h}$ and treated with TGF- $\beta 1(5 \mathrm{ng} / \mathrm{ml})$ for the indicated time periods. Cells were then harvested and cell lysates were subjected to western blotting analysis using the indicated antibodies. (B) TGF- $\beta 1$ induces Id1 expression in Smad2-null mouse embryonic fibroblasts (MEFs). Smad2-null MEFs were serum-starved for $12 \mathrm{~h}$ and then treated with BMP2 (2 h) or TGF- 1 1 (1.5 h), and in some cases with proteasome inhibitor MG-132, in the same medium. Cell lysates were subjected to western blotting analysis using the indicated antibodies.

is dispensable for Id 1 induction by TGF- $\beta 1$ or BMP. In the same experiment, we also treated Smad2KO MEFs with the proteasome inhibitor MG132 on top of BMP2 and TGF- $\beta 1$ (Figure 3C, lanes 3 and 5) or alone (Figure 3C, lane 6), and MG132 did not significantly increase the Id1 protein level when Id1 was strongly induced by either BMP2 or TGF- $\beta 1$ under the Smad2KO background.

\section{Smad3 is indispensable for TGF- $\beta 1$-triggered Id 1 induction}

Smad2 and Smad3, two close homologous that share $92 \%$ identities, are both activated by the same TGF- $\beta$ type I receptor to mediate specific and sometimes distinct TGF- $\beta 1$ responses. To compare the functions of Smad2 and Smad3 in mediating TGF- $\beta 1$-mediated Id 1 induction, we also generated MCF10A stable cells (shSmad3) that express Smad3 shRNA to knock down the expression of Smad3 protein. As shown in Figure 4A, depletion of $\mathrm{Smad} 3$ expression was evident, and it had no effect on Smad 2 or $\beta$-actin expression. In these shSmad 3 stable cells, Id 1 induction by TGF- $\beta 1$ was abolished. Thus, even though Smad2 protein was normally phosphorylated in response to TGF- $\beta 1$ in the shSmad 3 cells, Smad 2 apparently failed to compensate for the loss of Smad3 function. This result suggests that $\mathrm{Smad} 3$ is a rate-limiting and perhaps indispensable factor for Id 1 induction by TGF- $\beta 1$ in MCF10A cells.

To confirm the critical role of Smad3 in TGF- $\beta 1$ mediated induction of Id1, we also performed the experiment with Smad3-null MEFs. In Smad3-null MEFs, the ability of TGF- $\beta 1$ to induce Id 1 expression was abolished (Figure 4B, lane 4). To prove that the effect of Smad3 deletion is specific for TGF- $\beta 1$ responses and thus the integrity of BMP signaling is not affected, we examined
Id1 induction by BMP2. It is clear that Smad3-null MEFs still retained the response to BMP2 (Figure 4B, lane 2 ). The presence of the proteasome inhibitor MG132 in Smad3-null MEFs leads to a further increased accumulation of Id1 protein in the presence of BMP2 (Figure 4B, lane 3), suggesting that a quick turn-over mechanism by the 26S proteasome exists for Id1 protein in Smad3-null MEFs.

\section{Smad 3 and Smad4 bind to the mouse Id1 promoter}

We next attempted to analyze the mouse IdI gene promoter and investigate its chromatin alteration in response to TGF- $\beta$. The BMP-responsive element of the IdI promoter has been localized to a small fragment containing a cluster of SBE and binding sites of other transcription factors $[29,30]$. To determine the TGF- $\beta 1$ responsive element in the IdI promoter, we analyzed the $\sim 2-\mathrm{kb}$ sequence upstream of the transcriptional initiation site of the $I d 1$ gene. Within the proximal 2-kb region (nt -2000 to -1 ), twenty five potential SBE, GTCT or AGAC have been found. Three of these regions $(-1850$ to -1467 , -1265 to -926 , and -255 to +47 ) contain 8,6 and 2 potential SBE motifs, respectively (Figure 5A).

Since Smad3 is essential for mediating TGF- $\beta$-induced Id1 expression, we sought to determine if Smad3 and Smad4 (as an obligatory cofactor of Smad3) bind to the native $I d 1$ promoter in vivo, by chromatin immunoprecipitation (ChIP) assays with anti-Smad3 and anti-Smad4 antibodies. Since we have already excluded the involvement of Smad 2 for Id 1 activation by TGF- $\beta 1$, we chose Smad2-null MEFs for ChIP assays to avoid residual antibody cross-reactivity between Smad2 and Smad3. Four pairs of primers were then selected to amplify the indi- 

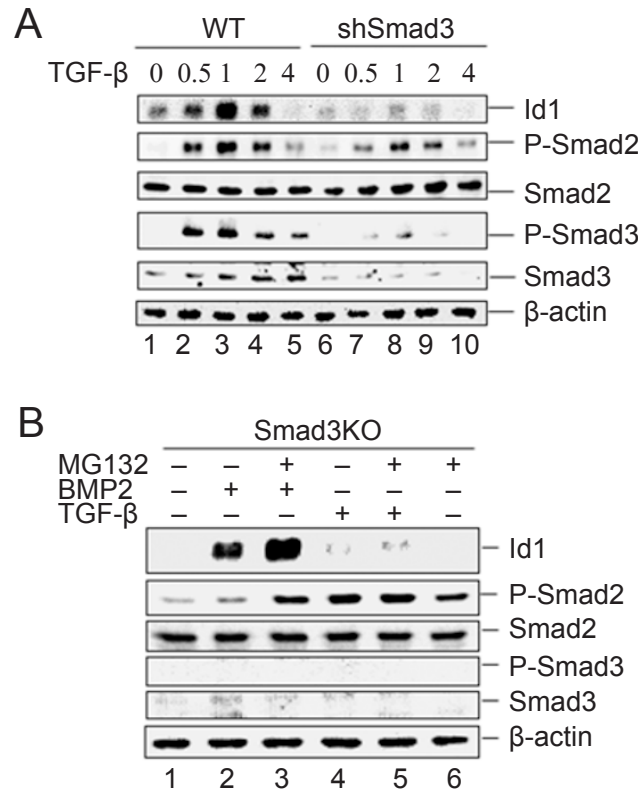

Figure 4 Smad3 is essential for Id1 induction by TGF- $\beta 1$. (A) Knockdown of Smad3 expression abolished TGF- $\beta$-induced Id1 expression in MCF10A cells. MCF10A cells control (WT) and stable cells expressing shRNA against Smad3 (shSmad3) were compared. Cell treatment, cell lysate harvest and western blotting analysis were essentially the same as described in Figure 3. (B) TGF- $\beta 1$ induces Id1 expression in Smad3-null mouse embryonic fibroblasts (MEFs). Cell treatment, cell lysate harvest and western blotting analysis were essentially the same as described in Figure 3.

cated specific regions in the mouse Id 1 promoter (Figure $5 \mathrm{~A}$ ), with the downstream sequence $n t+757$ to +1114 as a negative control. As shown in Figure 5B, Smad3 bound to only one region of the mouse $I d l$ promoter ( -1265 to -926$)$ after $1 \mathrm{~h}$ of TGF- $\beta 1$ treatment. In the absence of TGF- $\beta$ stimulation, anti-Smad 3 antibody could not enrich any region of the mouse $I d 1$ promoter. Smad4 was capable of binding to all three upstream promoter regions in the presence, but not absence, of TGF- $\beta$ (Figure 5C). As a negative control, neither Smad3 nor Smad4 immunoprecipitation could enrich the $3^{\prime}$ region $(+757 /+1114)$ (Figure 5B and 5C). Our results suggest that Smad3 and Smad4 only bind to the upstream region of the mouse Id 1 promoter after TGF- $\beta$ stimulation, consistent with the indispensable role of Smad3 protein in the Id1 induction by TGF- $\beta$.

\section{TGF- $\beta 1$ induces histone acetylation at the mouse IdI promoter}

It is well documented that acetylation of lysine residues in the N-terminal tails of histones $\mathrm{H} 3$ and $\mathrm{H} 4$ correlates positively with gene transcription $[31,32]$. Upon
TGF- $\beta$ stimulation, activated Smads can recruit transcription coactivators such as histone acetyltransferase $\mathrm{CBP} / \mathrm{p} 300$ to the promoter [33-35]. To analyze the acetylation status of histones $\mathrm{H} 3$ and $\mathrm{H} 4$ during the activation of IdI gene by TGF- $\beta 1$, we carried out ChIP assays with anti-acetyl histone H3K14 and anti-acetyl histone H4 antibodies.

We assessed the presence of acetylated $\mathrm{H} 3$ and $\mathrm{H} 4$ in the same Smad-binding regions by ChIP assays. As shown in Figure 5D and 5E, TGF- $\beta 1$ stimulation ( 1 and $3 \mathrm{~h}$ ) induced a significant increase in acetylation of both histone $\mathrm{H} 3$ and histone $\mathrm{H} 4$ associated with all the three upstream regions of the $I d 1$ gene promoter. However, the region of $\mathrm{nt}-1850$ to -1467 appeared to have higher levels of acetylated $\mathrm{H} 3 / \mathrm{H} 4$ than the other two regions. The levels of $\mathrm{H} 3 / \mathrm{H} 4$ acetylation gradually decreased after TGF- $\beta 1$ treatment for a long time and reached the basal level at $6 \mathrm{~h}$, which correlates well with the repressed state of the $I d 1$ promoter. These results suggest that histone $\mathrm{H} 3$ and $\mathrm{H} 4$ acetylation is associated with the transactivated Id 1 promoter in the early response phase to TGF- $\beta 1$.

\section{Discussion}

This study provides a mechanistic view on how the Idl gene is regulated by TGF- $\beta$. We found that Smad3, but not Smad2, is required for the immediate early induction of the IdI gene in both human and mouse cells. Smad3, together with Smad4, binds to the Id1 promoter. The ability of TGF- $\beta 1$ to induce acetylation of H3 and $\mathrm{H} 4$ in the same promoter region suggests that the Smad3/4 activator complex likely recruits coactivators such as $\mathrm{p} 300 / \mathrm{CBP}$ to facilitate transcriptional induction of the IdI gene. However, long-term TGF- $\beta 1$ stimulation $(>4 \mathrm{~h})$ resulted in transcriptional repression of the $I d I$ gene, which depends on new protein synthesis, as previously reported [5]. It has been shown that ATF3 interacts with Smad3 and binds to the CRE/ATF binding sequence in this region to repress the expression of Id 1 after $2 \mathrm{~h}$ of TGF- $\beta 1$ stimulation [5]. It has also been reported that Smad3 can interact with HDAC4 and HDAC5 to repress the expression of Runx2 gene [36]. It is conceivable that ATF3, whose expression is induced by TGF- $\beta 1$, recruits HDACs to the Smad complex, thereby converting it from an activator to a repressor complex. We found that the timing of transcriptional repression is well correlated with decreases in the levels of acetylated $\mathrm{H} 3$ and $\mathrm{H} 4$ (Figure 5D and 5E). Therefore, regulation of the $I d 1$ gene by TGF- $\beta 1$ is a complicated event, shifting from an early induction phase to a late repression phase.

The biphasic regulation of Id1 implicates a complex 
A

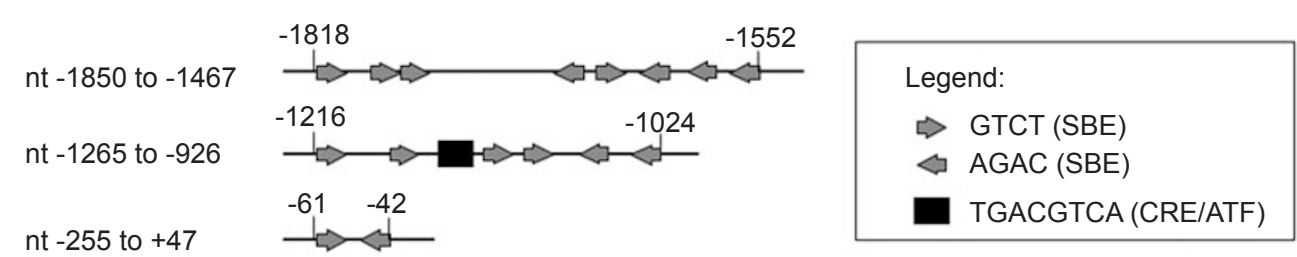

B
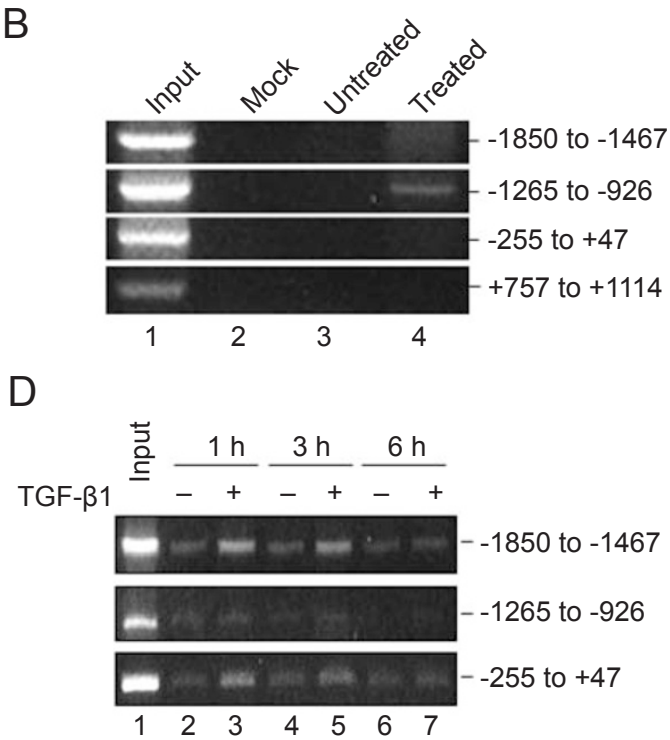

C

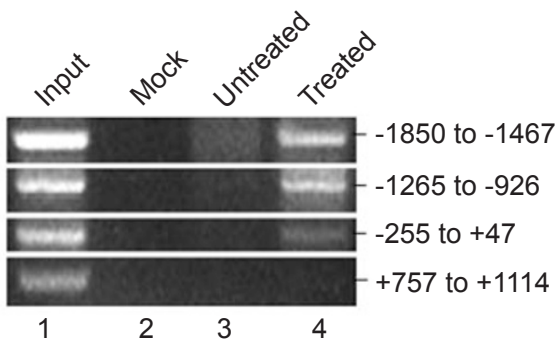

E

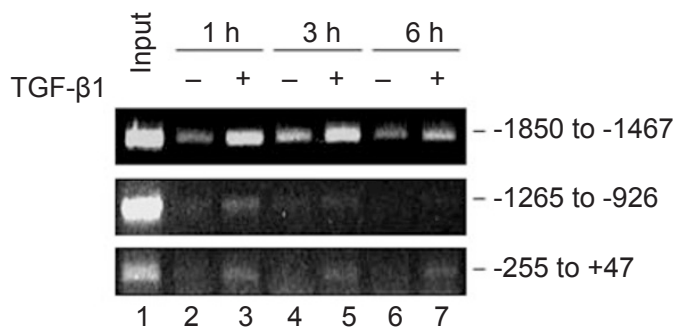

Figure 5 TGF- $\beta 1$ induces Smad3 and Smad4 binding to and histone acetylation on the mouse Id1 promoter. (A) Schematic presentation of the upstream sequence of the mouse ld1 promoter. Smad-binding element (SBE) and cAMP-responsive element/ATF binding (CRE/ATF) are shown. (B) TGF- $\beta 1$ induces Smad3 binding to the mouse Id1 promoter. Smad2-null MEFs were untreated, mock-treated or TGF- $\beta 1$-treated for $1.5 \mathrm{~h}$. Chromatin immunoprecipitation (ChIP) assays were carried out using anti-Smad2/3 (E20, Santa Cruz Biotechnology). ChIP products were amplified by using PCR, which were then separated by a $2 \%$ agarose gel. (C) TGF- $\beta 1$ induces Smad4 binding to the mouse Id1 promoter. Smad2-null MEFs were untreated, mock-treated or TGF- $\beta 1$-treated for $1.5 \mathrm{~h}$. ChIP assays were carried out using anti-Smad4 (B8, Santa Cruz Biotechnology), essentially as described in the text and in panel B. (D) TGF- $\beta 1$ induces histone H3 acetylation on the mouse Id1 promoter. Smad2-null MEFs were untreated, mock-treated or TGF- $\beta 1$-treated for 1,3 or $6 \mathrm{~h}$. ChIP assays were carried out using antiActH3 antibody (Cell Signaling Technology), essentially as described in the text and in panel B. (E) TGF- $\beta 1$ induces histone $\mathrm{H} 4$ acetylation on the mouse Id1 promoter. Smad2-null MEFs were untreated, mock-treated or TGF- $\beta 1$-treated for 1, 3 or $6 \mathrm{~h}$. ChIP assays were carried out using anti-ActH4 antibody (Cell Signaling Technology), essentially as described in the text and panel B.

role of Id 1 in modulating TGF- $\beta 1$ responses. Although the exact role of Id1's early induction in TGF- $\beta$ responses awaits further investigation, certain possible roles of Id 1 in regulating TGF- $\beta$ signaling can be envisioned. As Id1 is an inhibitor of differentiation via its association with bHLH transcription factors $[6,14]$, the early induction of Id 1 may confer TGF- $\beta$ the ability to inhibit differentiation by controlling the activities of bHLH proteins. For instance, considering that TGF- $\beta$ is a potent inhibitor of myogenic differentiation [37], it is possible that TGF- $\beta$ induced Id1 early expression contributes to early inhibition or delay of the myogenic function of transcription factors such as MyoD during skeletal muscle differentia- tion. Similarly, a previous report clearly shows that Id1 induction regulates smooth muscle cell differentiation in response to TGF- $\beta$, during which USF, a bHLH factor, is involved in E box-dependent expression of smooth muscle genes [27]. Therefore, it is tempting to speculate that in response to TGF- $\beta$, Id 1 induction contributes to inhibition of bHLH transcription factors that are involved in the differentiation of various cell lineages.

Repression of Id 1 in the late phase of gene expression in response to TGF- $\beta$ is also critical to maintain proper cellular responses to TGF- $\beta$. As there is good evidence demonstrating that Id1 promotes cell proliferation likely through inhibition of cyclin-dependent kinase inhibitors 
(CKIs) $[6,10]$, induction of Id1 would be contradictory to the ability of TGF- $\beta$ to arrest cells in the G1 phase of cell cycle. Thus, it may be necessary to remove the excess amount of Id 1 to ensure the antiproliferative response to TGF- $\beta$ in epithelial cells such as HaCaT keratinocytes and MCF10A mammary epithelial cells. During the immediate early phase of response to TGF- $\beta$ (before $4 \mathrm{~h}$ ), CKIs such as p21 and p15 are transcriptionally induced along with Id1 and its repressor ATF3. Four hours after TGF- $\beta$ stimulation, cell cycle inhibitors continue to rise while Id1 becomes transcriptionally repressed by ATF3. Loss of Id1 expression also coincides with TGF$\beta$-dependent repression of c-Myc, a factor that positively controls Id1 expression [38]. It has been reported that down-regulation of Id1 expression is associated with TGF- $\beta$-induced cell cycle arrest in prostate epithelial cells $[39,40]$. The negative role of Id 1 in TGF- $\beta$-induced antiproliferative response is further supported by previous studies showing that forced overexpression of Ids in human keratinocytes and endothelial cells delays senescence, probably through inactivation of CKIs [41-43]. Together with these studies, our findings provide valuable information on the regulation of the $I d l$ gene and its potential functions in influencing TGF- $\beta$ responses during cell proliferation and differentiation.

\section{Materials and Methods}

\section{Cell cultures, TGF- $\beta 1$ treatment, antibodies and western blotting}

Human mammary epithelial MCF10A cells were maintained in D-MEM/F-12 medium complemented with 5\% horse serum, $10 \mu \mathrm{g} / \mathrm{ml}$ insulin (Sigma), $0.5 \mu \mathrm{g} / \mathrm{ml}$ hydrocortisone (Sigma), 0.02 $\mu \mathrm{g} / \mathrm{ml}$ epidermal growth factor (Sigma) and $1 \%$ of penicillin and streptomycin (Invitrogen). HeLa cells, Smad2-/- and Smad3-/MEFs were cultured in D-MEM medium supplemented with $15 \%$ of fetal bovine serum (FBS) and 1\% of penicillin and streptomycin. $\mathrm{HaCaT}$ cells were maintained in MEM medium $+1 \%$ of nonessential amino acids (NEAA, Invitrogen) $+10 \%$ of FBS and $1 \%$ of penicillin and streptomycin.

For Id 1 induction, MCF10A cells were washed once with and maintained in serum-free medium for $12 \mathrm{~h}$ before TGF- $\beta 1$ treatment $(5 \mathrm{ng} / \mathrm{ml})$. For cycloheximide (CHX, Sigma) treatment, it was added to the medium at $100 \mu \mathrm{M}$ for $30 \mathrm{~min}$ prior to TGF- $\beta 1$ stimulation. Endogenous Id1 was detected using a polyclonal antiId1 antibody (C2, Santa Cruz Biotechnology). Endogenous Smad2, Smad 3 and phosphorylated Smad 2 were detected using polyclonal antibodies from Zymed. Anti-phosphorylated Smad3 was a kind gift of Dr Ed Leof (Mayo Clinic). Anti- $\beta$-actin, a monoclonal antibody, was obtained from Sigma. Western analysis was detected by Western Lightning Kit (Perkin-Elmer Life Science, Inc.) or SuperSignal West Dura and Femto (Pierce) with Kodak Image Station 440.

\section{$R T-P C R$}

Total RNAs were prepared from TGF- $\beta 1$-treated or untreated MCF10A cells with Trizol reagent (Invitrogen). The first-strand cDNAs were synthesized with $2.5 \mu \mathrm{g}$ of total RNA. All real-time RT-PCR quantifications were carried out with the 7300 real-time PCR system and TaqMan reagents with triplicate (Applied BioSystem), and regular RT-PCRs were performed in a PCR machine (PTC-200 Peltier Thermal Cycler of DNA Engine).

\section{Retroviral infection}

Retroviral vector pSRG expressing shRNAs against human Smad 2 and Smad3 have been previously described [44]. pSRGshSmad2 or pSRG-shSmad3 DNA was co-transfected with the plasmid pCL into $293 \mathrm{~T}$ cell using $\mathrm{CaCl}_{2}$ method to produce retrovirus particles. MCF10A cells were infected overnight by freshly prepared retroviruses and selected puromycin $(2.0 \mu \mathrm{g} / \mathrm{ml}$, Sigma $)$. All puromycin-resistant colonies were pooled together for further studies.

\section{Cell transfection and luciferase assays}

Mouse Id1-luciferase constructs were kind gifts of Dr Benezra [45]. HepG2 cells were co-transfected with $0.5 \mu \mathrm{g}$ of mouse Id1luciferase reporter plasmid and $0.05 \mu \mathrm{g}$ of SV40 $\beta$-galactosidase plasmid by FuGene 6 in 12-well plates according to the manufacturer's instructions (Roche). At $48 \mathrm{~h}$ after transfection, cells were treated with TGF- $\beta 1(5 \mathrm{ng} / \mathrm{ml})$ overnight and harvested with reporter lysis buffer (Promega). All assays were repeated at least twice with duplicates in the Microplate Luminometer LB96V (EG\&G BERTHOLD).

\section{ChIP assays}

ChIP assays were carried out with chromatins prepared as reported previously [46] from Smad2-/- MEFs with or without TGF- $\beta 1$ treatment. Briefly, $2 \mu \mathrm{g}$ of anti-Smad4 (B8, Santa Cruz Biotechnology) or anti-Smad2/3 (E20, Santa Cruz Biotechnology), and $50 \mathrm{U}$ of chromatin at A260 were used for each ChIP assay. ChIP products were amplified by primers in the mouse Idl upstream sequences as follows:

-1 850F: 5'-GTG CCC TAG ATA TAC CAA TAC TT-3'

-1 467R: 5'-TTC TGG ACT CCG AAA CTG ACT CA-3'

-1 265F: 5'-GGA GGT AAG TTG ACC CTT GGT CA-3'

-926R: 5'-TTG AAG GCC TCC GAG CAA GCT CT-3'

-255F: 5'-ACC GCA AAA TTA GCT TAG TCT CT-3'

+47R: 5'-AAC AGA GTG TGG GAA GAG AAC AA-3'

+757F: 5'-GAC GGT ACC AGT GGG TAG AGG GTT TGA T-3'

+1 114R: 5'-GGA AGA TCT CAT AGA ACT ATT GTA AAA CAA TAT-3'

PCR products were separated by a $2 \%$ agarose gel.

\section{Acknowledgments}

We thank Robert Benezra (Sloan-Kettering Institute, NY, USA) for Id1-luc reporter constructs and Ed Leof (Mayo Clinic, MN, USA) for anti-phospho-Smad3 antibody. We are grateful to XinHua Feng (Baylor College of Medicine, TX, USA)for critically reading the manuscript and stimulating discussions. This research was supported by NIH grant R01DK073932, USA and partly by the Baylor Breast Center SPORE career development award, USA. 


\section{References}

1 ten Dijke P, Heldin CH, eds. Smad Signal Transduction. Dordrecht: Springer, 2006.

2 Derynck R, Miyazono K. The TGF- $\beta$ Family. Cold Spring Harbor, NY: Cold Spring Harbor Laboratory Press, 2008.

3 Feng X-H, Derynck R. Specificity and versatility in TGF- $\beta$ signaling through Smads. Annu Rev Cell Dev Biol 2005; 21:659-693.

4 Feng X-H, Lin X, Derynck R. Smad2, Smad3 and Smad4 cooperate with $\mathrm{Sp} 1$ to induce $\mathrm{p} 15^{\mathrm{Ink} 4 \mathrm{~B}}$ transcription in response to TGF- $\beta$. EMBO J 2000; 19:5178-5193.

5 Kang Y, Chen CR, Massagué J. A self-enabling TGF $\beta$ response coupled to stress signaling: Smad engages stress response factor ATF3 for Id1 repression in epithelial cells. Mol Cell 2003; 11:915-926.

6 Perk J, Iavarone A, Benezra R. Id family of helix-loop-helix proteins in cancer. Nat Rev Cancer 2005; 5:603-614.

7 Andres-Barquin PJ, Hernandez MC, Israel MA. Id genes in nervous system development. Histol Histopathol 2000; 15:603-618.

8 Benezra R, Rafii S, Lyden D. The Id proteins and angiogenesis. Oncogene 2001; 20:8334-8341.

9 Yokota Y, Mori S. Role of Id family proteins in growth control. J Cell Physiol 2002; 190:21-28.

10 Ruzinova MB, Benezra R. Id proteins in development, cell cycle and cancer. Trends Cell Biol 2003; 13:410-418.

11 de Candia P, Benera R, Solit DB. A role for Id proteins in mammary gland physiology and tumorigenesis. Adv Cancer Res 2004; 92:81-94.

12 Sugai M, Gonda H, Nambu Y, Yokota Y, Shimizu A. Role of Id proteins in B lymphocyte activation: new insights from knockout mouse studies. J Mol Med 2004; 82:592-599.

13 Wong YC, Wang X, Ling MT. Id-1 expression and cell survival. Apoptosis 2004; 9:279-289.

14 Sun XH, Copeland NG, Jenkins NA, Baltimore D. Id proteins Id1 and Id2 selectively inhibit DNA binding by one class of helix-loop-helix proteins. Mol Cell Biol 1991; 11:5603-5611.

15 Langlands K, Yin X, Anand G, Prochownik EV. Differential interactions of Id proteins with basic-helix-loop-helix transcription factors. J Biol Chem 1997; 272:19785-19793.

16 Vinals F, Ventura F. Myogenin protein stability is decreased by BMP-2 through a mechanism implicating Id1. J Biol Chem 2004; 279:45766-45772.

17 Einarson MB, Chao MV. Regulation of Id1 and its association with basic helix-loop-helix proteins during nerve growth factor-induced differentiation of PC12 cells. Mol Cell Biol 1995; 15:4175-4183.

18 Parrinello S, Lin CQ, Murata K, et al. Id-1, ITF-2, and Id-2 comprise a network of helix-loop-helix proteins that regulate mammary epithelial cell proliferation, differentiation, and apoptosis. J Biol Chem 2001; 276:39213-39219.

19 Zheng W, Wang H, Xue L, Zhang Z, Tong T. Regulation of cellular senescence and $\mathrm{p} 16^{\mathrm{INK} 4 \mathrm{~A}}$ expression by Id1 and E47 proteins in human diploid fibroblast. J Biol Chem 2004; 279:31524-31532.

20 Ohtani N, Zebedee Z, Huot TJ, et al. Opposing effects of Ets and Id proteins on $16^{\mathrm{INK} 4 \mathrm{~A}}$ expression during cellular senes- cence. Nature 2001; 409:1067-1070.

21 Inoue T, Shoji W, Obinata M. MIDA1, an Id-associating protein, has two distinct DNA binding activities that are converted by the association with Id1: a novel function of Id protein. Biochem Biophys Res Commun 1999; 266:147-151.

22 Nieborowska-Skorska M, Hoser G, Rink L, et al. Id1 transcription inhibitor-matrix metalloproteinase 9 axis enhances invasiveness of the breakpoint cluster region/Abelson tyrosine kinase-transformed leukemia cells. Cancer Res 2006; 66:41084116.

23 Singh J, Itahana Y, Parrinello S, Murata K, Desprez PY. Molecular cloning and characterization of a zinc finger protein involved in Id-1-stimulated mammary epithelial cell growth. $J$ Biol Chem 2001; 276:11852-11858.

24 Volpert OV, Pili R, Sikder HA, et al. Id1 regulates angiogenesis through transcriptional repression of thrombospondin-1. Cancer Cell 2002; 2:473-483.

25 Hasskarl J, Duensing S, Manuel E, Munger, K. The helix-loophelix protein ID1 localizes to centrosomes and rapidly induces abnormal centrosome numbers. Oncogene 2004; 23:19301938.

26 Miyazono K, Miyazawa K. Id: a target of BMP signaling. Sci STKE 2002; 151:PE40.

27 Chambers RC, Leoni P, Kaminski N, Laurent GJ, Heller RA. Global expression profiling of fibroblast responses to transforming growth factor-betal reveals the induction of inhibitor of differentiation-1 and provides evidence of smooth muscle cell phenotypic switching. Am J Pathol 2003; 162:533-546.

28 Wiercinska E, Wickert L, Denecke B, et al. Id1 is a critical mediator in TGF- $\beta$-induced transdifferentiation of rat hepatic stellate cells. Hepatology 2006; 43:1032-1041.

29 Lopez-Rovira T, Chalaux E, Massagué J, Rosa JL, Ventura F. Direct binding of Smad1 and Smad4 to two distinct motifs mediates bone morphogenetic protein-specific transcriptional activation of Id1 gene. J Biol Chem 2002; 277:3176-3185.

30 Korchynskyi O, ten Dijke P. Identification and functional characterization of distinct critically important bone morphogenetic protein-specific response elements in the Id1 promoter. J Biol Chem 2002; 277:4883-4891.

31 Agalioti T, Chen G, Thanos D. Deciphering the transcriptional histone acetylation code for a human gene. Cell 2002; 111:381392.

32 Kurdistani SK, Tavazoie S, Grunstein M. Mapping global histone acetylation patterns to gene expression. Cell 2004; 117:721-733.

33 Feng X-H, Zhang Y, Wu R-Y, Derynck R. The tumor suppressor Smad4/DPC4 and transcriptional adaptor CBP/p300 are coactivators for Smad3 in TGF- $\beta$-induced transcriptional activation. Genes Dev 1998; 12:2153-2163.

34 Janknecht R, Wells NJ, Hunter T. TGF-beta-stimulated cooperation of Smad proteins with the coactivators $\mathrm{CBP} / \mathrm{p} 300$. Genes Dev 1998; 12:2114-2119.

35 Shen X, Hu PP, Liberati NT, Datto MB, Frederick JP, Wang XF TGF-beta-induced phosphorylation of Smad3 regulates its interaction with coactivator $\mathrm{p} 300 / \mathrm{CREB}-$ binding protein. $\mathrm{Mol}$ Biol Cell 1998; 9:3309-3319.

36 Kang JS, Alliston T, Delston R, Derynck R. Repression of Runx 2 function by TGF- $\beta$ through recruitment of class II histone deacetylases by Smad3. EMBO J 2005; 24:2543-2555. 
37 Derynck R, Piek E, Schneider RA, Choy L, Alliston T. TGF- $\beta$ family signaling in mesenchymal differentiation. In: Derynck R, Miyazono K, eds. The TGF- $\beta$ Family. Cold Spring Harbor: Cold Spring Harbor Laboratory Press, 2008:613-666.

38 Swarbrick A, Akerfeldt MC, Lee CS, et al. Regulation of cyclin expression and cell cycle progression in breast epithelial cells by the helix-loop-helix protein Id1. Oncogene 2005; 24:381-389.

39 Di K, Ling MT, Tsao SW, Wong YC, Wang X. Id-1 modulates senescence and TGF- $\beta 1$ sensitivity in prostate epithelial cells. Biol Cell 2006; 98:523-533.

40 Ling MT, Wang X, Tsao SW, Wong YC. Down-regulation of Id- 1 expression is associated with TGF- $\beta 1$-induced growth arrest in prostate epithelial cells. Biochim Biophys Acta 2002; 1570:145-152.

41 Alani RM, Young AZ, Shifflett CB. Id1 regulation of cellular senescence through transcriptional repression of $\mathrm{p} 16 / \mathrm{Ink} 4 \mathrm{a}$.
Proc Natl Acad Sci USA 2001; 98:7812-7816.

42 Nickoloff BJ, Chaturvedi V, Bacon P, Qin JZ, Denning MF, Diaz Mo. Id-1 delays senescence but does not immortalize keratinocytes. J Biol Chem 2000; 275:27501-27504.

43 Tang J, Gordon GM, Nickoloff BJ, Foreman KE. The helixloop-helix protein Id-1 delays onset of replicative senescence in human endothelial cells. Lab Invest 2002; 82:1073-1079.

44 Lin X, Duan X, Liang YY, et al. PPM1A functions as a Smad phosphatase to terminate TGF- $\beta$ signaling. Cell 2006; 125:915-928.

45 Tournay O, Benezra R. Transcription of the dominant-negative helix-loop-helix protein Id1 is regulated by a protein complex containing the immediate-early response gene Egr-1. Mol Cell Biol 1996; 16:2418-2430.

46 Shang Y, Hu X, DiRenzo J, Lazar MA, Brown M. Cofactor dynamics and sufficiency in estrogen receptor-regulated transcription. Cell 2000; 103:843-852. 